\title{
Pharmacognostic Profile of Root and Stem of Indigofera Tirunelvelica Sanjappa
}

\author{
Srinivasa Naidu Parijatham Kanchana ${ }^{1}$, Agnel Arul John Nayagam²,*, Sandra Horta ${ }^{3}$
}

\section{Srinivasa Naidu Parijatham Kanchana', Agnel Arul John Nayagam $^{2, *}$, Sandra Horta ${ }^{3}$ \\ 'Department of Biochemistry, St, Francis College for Women (Autonomous), Hyderabad, Telangana, INDIA. \\ ${ }^{2} P G$ and research Department of Biochemistry, Srimad Andavan Arts and Science College (Autonomous), Tiruchirappalli, Tamil Nadu, INDIA. ${ }^{3}$ Assistant Professor, Department of Biochemistry, St, Francis College for Women (Autonomous), Hyderabad, Telangana, INDIA.}

\section{Correspondence}

\section{Dr. N. AGNEL ARUL JOHN}

Associate Professor, PG and Research Department of Biochemistry, Srimad Andavan Arts and Science College

(Autonomous), Tiruchirappalli, Tamil Nadu, INDIA

Phone no. +91-70102 23121

E-mail: aruljohnagnel@gmail.com

History

- Submission Date: 26-08-2019;

- Review completed: 04-10-2019;

- Accepted Date: 22-10-2019.

DOI : 10.5530/pj.2019.11.241

Article Available online http://www.phcogj.com/v11/i6s

\section{Copyright}

(C) 2019 Phcogj.Com. This is an openaccess article distributed under the terms of the Creative Commons Attribution 4.0 International license.

\section{ABSTRACT}

Background: The focus on herbal plants as medicine is increasing rapidly because of their efficacy and less side effects. The medicinal plants are great alternative as they are renewable and non exhaustive resources. In India these medicinal plants have been part of the people's life dating back from centuries. Objectives: The present study is aimed to evaluate anatomical characterization of stem and root of Indigofera tirune/velica Sanjappa for the first time which can be used in the identification and standardisation of Indigofera tirune/velica Sanjappa. Results: The stem and root of the plant were evaluated for their microscopic features. In that histochemical localisation of secondary metabolites and transverse section of stem and root were studied. The histochemical localisation result reveals the presence of terpenoids, alkaloids, flavonoids and lignin were found in epidermal, cortical and xylem regions of the stem. Alkaloids, Terpenoids, phenols and lignin were found in the different areas of root. Conclusion: The present study thus emphasis the potentiality of the plant as a drug.

Key words: Indigofera tirune/velica Sanjappa, Root, Stem, Alkaloid, Flavonoid.

\section{INTRODUCTION}

In this era of modern world technology has become the part of every phase of life which might also have been the reason for many diseases like never before. There are plenty of drugs available in the market but unfortunately with many side effects. So it is the need of the hour to look back our traditional methods of using medicinal plants as an alternative. Looking back at the last 2000 years of the history of medicine, mankind has mainly used plants as the best source of medicine. ${ }^{1}$ Medicinal plants are playing very active role in traditional medicines for the treatment of various ailments. ${ }^{2}$ Due to the lack of documentation of some of the medicinal plants it is important that pharmacognostic study has to be done to authenticate the plant's identity. Correct characterization and quality assurance of starting material is an essential step to ensure reproducible quality of herbal medicine which will help us to justify its safety and efficacy. ${ }^{3-6}$ This study also helps to evaluate the quality control, Efficacy and safety side as a drug.

Indigofera tirunelvelica Sanjappa (IT) is a recently discovered plant found in South Indian town called Tirunelveli, Tamilnadu which belongs to the family Papilionace. ${ }^{7}$ The pharmacognostic standardisation of this plant has not been reported so far. Microscopical, anatomical and morphological studies are used for the plant's identification. But morpho-anatomical documentation is the simplest qualitative method to avoid falsification and adulteration of the drug. ${ }^{8}$ The structural analysis pinpoints idiosyncratic aspects that can be effective in determining the accuracy of medicinal plant species. ${ }^{9-11}$ Apart from anatomical study
Histochemical localisation of secondary metabolites were also performed in this study. Secondary metabolites present in a plant can be considered as its chemical individuality as their composition differ from species to species. ${ }^{12}$ The present paper reports the anatomical and histochemical localisation of the rare and a new plant Indigofera tirunelvelica Sanjappa.

\section{MATERIALS \& METHODS}

\section{Plant collection}

The plant was collected in the Tirunelveli, Tamil Nadu during the month of Jan 2019. Plant was authenticated by Dr.V.Chelladurai, Professor, Department of Botany Medicinal plant Survey for Siddha, Government of India. Care was taken to select the healthy and fully grown plants.

\section{Microscopic evaluations}

Microscopy evaluations were done on both qualitative and anatomical study. All the evaluations were performed using labomed compound microscope.

\section{Histochemical localisation studies}

For Histochemical localisation analysis of stem, and root were made by using microtome. Staining procedure was performed as per standard procedure. Various identifying characters were studied with staining.

\section{Transverse sectional study}

TS study of stem and root performed using standard procedure. 


\section{RESULTS}

\section{T. S of Root of Indigofera tirunelvelica Sanjappa.}

The T.S of root of Indigofera tirunelvelica Sanjappa is circular, The study of T.S. shows the presence of periderm, a cortical protective layer, discontinues patches of sclereids, narrow secondary phloem and dense large compact xylem. The periderm is made up of 3-4 cell layers disintegrated or squashed thin walled cells. Periderm is followed by 6-7 layers of irregular, large thin walled parenchyma cells. In the cortical region discontinuous long and wide patches of sclerenchymatous (SC) cells with thick wall and narrow lumen present. The stealer region showed distinct xylem region occupying major portion. The secondary phloem is well developed and consists of 6-8 layers of irregularly arranged cells. Meduallary rays are up to two cells wide. The xylem portion consists of thick, compact xylem fibers, thick lignified xylem parenchyma with intercellular space. Xylem vessels circular and solitary arranged in radial multiples. Distinct uni and biseriate rays present. The xylem ray cells contains simple round starch grains (Figures 1-4).

\section{T. S of stem of Indigofera tirunelvelica Sanjappa}

T.S of stem is circular in sectional view and rarely there is a presence the trichomes on surface of the stem. T.S revealed the presence of epidermis, cortex, vascular bundles and pith region. The stem has distinct and continuous epidermal layer made up of small rectangular thick walled cells. The epidermis is followed by 2 -3 layers of thick walled polygonal collenchyma cells and followed by 1-2 layers of parenchyma cells. Next to the parenchyma cells a discontinuous many celled patches of cortical fibers and stone cells are seen. The vascular bundle consists of continuous narrow irregularly compactly arranged secondary phloem elements. Xylem region contains primary and secondary vessel elements. Xylem vessel elements are arranged in an irregular radial rows and ray present between rows. Lignified xylem fibers form major portion of secondary xylem. The xylem vessels are circular, wide, thick walled. The Pith region consists of compactly arranged large round shaped thin walled parenchyma cells (Figures 5-8).

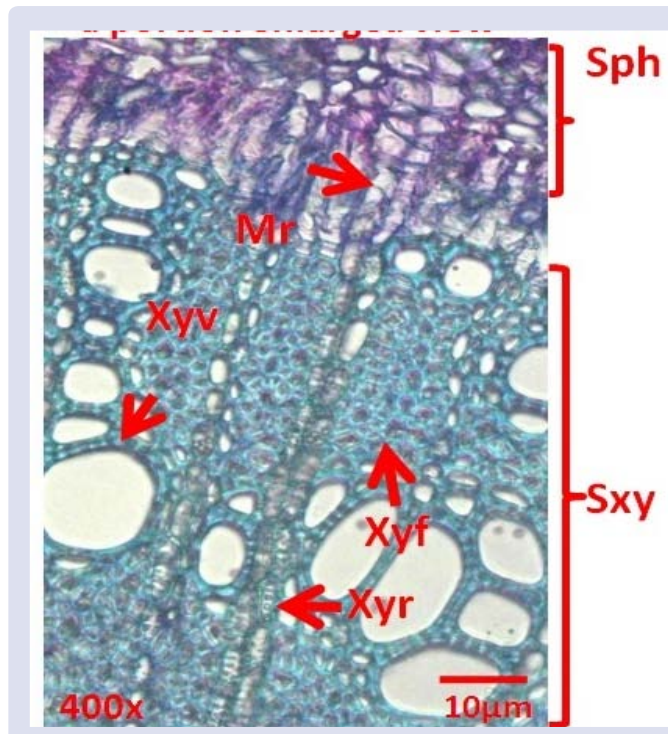

Figure 1: T.S of I. tirunelvelica Root A portion enlarged view.

Mr: Medullary ray; Sph: Secondary phloem; Sxy: Secondary xylem; Xyf: Xylem fibers; Xyr: Xylem ray; Xyv: Xylem vessel.

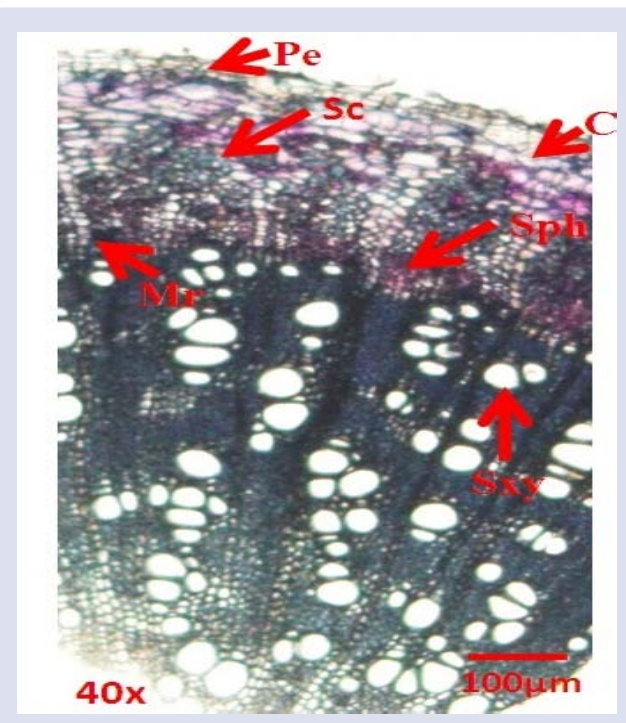

Figure 2: T.S of I. tirunelvelica root.

Co: Cortex; Mr: Medullary ray periderm; Sc: Scle; Sph: Secondary phloem; Sxy: Secondary xylem.

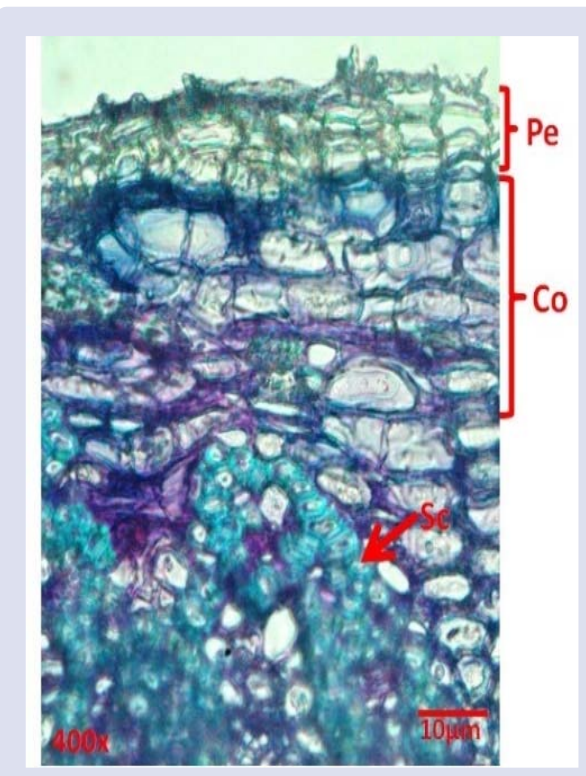

Figure 3: T.S of I. tirunelvelica Root A portion enlarged view.

e: Periderm; Co: Cortex; Sc: Sclereids.

\section{Histochemical Analysis of stem of Indigofera tirunelvelica} Sanjappa

Histochemical analysis of stem shows that the terpenoids and alkaloids are present in epidermal, cortical and xylem region. Alkaloids are also seen in, phloem region. Flavonoids and lignin are present in Epidermal, Cortical and xylem regions respectively (Figures 9 and 10) (Table 1).

\section{Histochemical Analysis of root of Indigofera tirunelvelica} Sanjappa.

Histochemical analysis of root shows that the terpenoids are present in periderm and cortical cells. Sclereids and xylem region contain both alkaloids and terpenoids. In contrast to stem root has lignin in both xylem and phloem region and tannin only in xylem rays (Figures 11 and 12) (Table 2). 


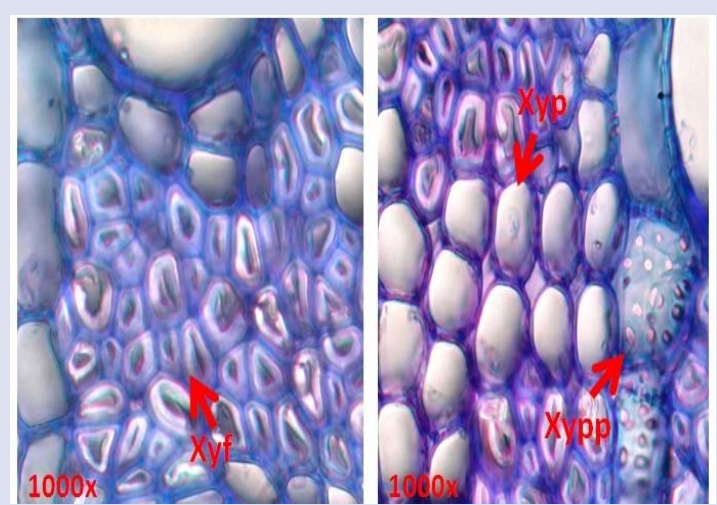

Figure 4: T.S of I. tirunelvelica root xylem fiber and xylem parenchyma.

Xyf: Xylem fibers; Xyp: Xylem parenchyma; Xyrp: Xylem ray with pits.

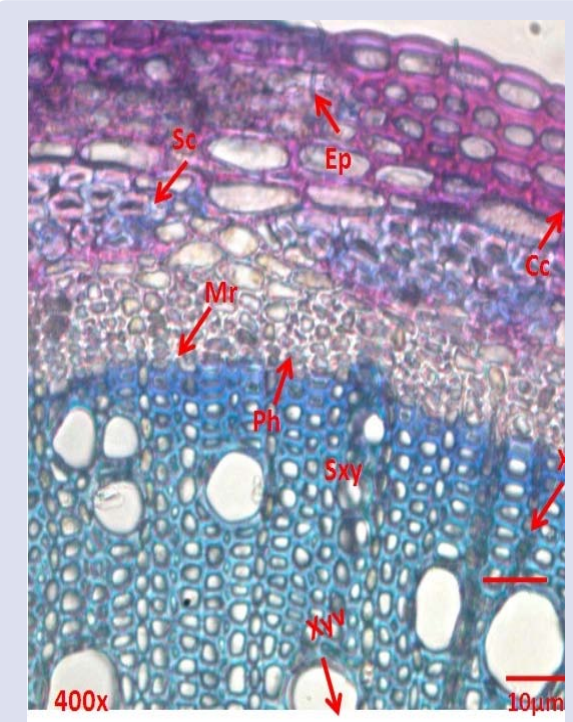

Figure 5: T.S. of Indigofera tirunelvelica stem a portion enlarged view.

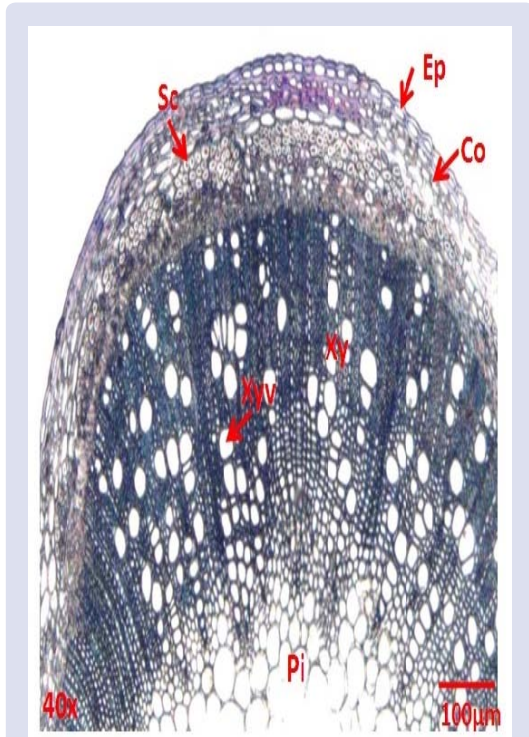

Figure 6: T.S. of Indigofera tirunelvelica stem a portion enlarged view.

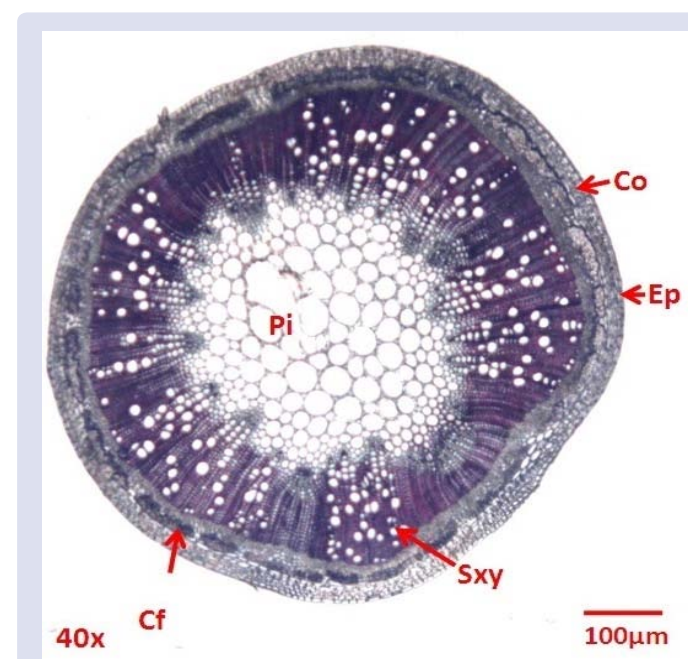

Figure 7: T.S. of Indigofera tirunelvelica entire stem.

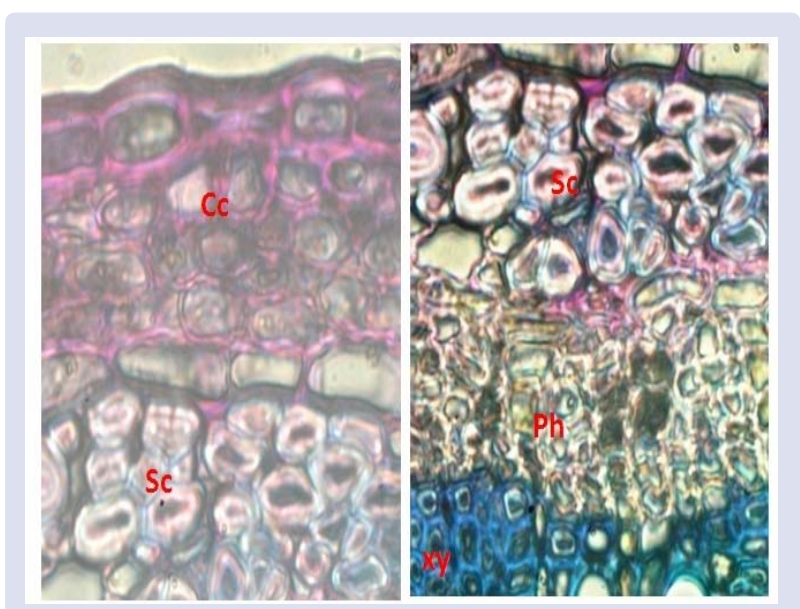

Figure 8: T.S. of Indigofera tirunelvelica stem - a portion of enlarged view.

Cc: Collenchyma; Co: Cortex; Ep: Epidermis; Mr: Medullary ray; Ph: Phloem; Pi: Pith; Sc: Sclereids; Sxy: Secondary xylem; Xy: Xylem; Xyr: Xylem ray cels; Xyv: Xylem vessels.

\section{DISCUSSION}

The botanical identity of the plants are established by performing pharmacognostic studies which includes microscopical studies mostly anatomical and histochemical analysis. Pharmacognostic parameters are widely used for the identification of medicinal plants and also to detect adulteration in drugs. ${ }^{13}$ Histochemical studies confirmed the presence of various secondary metabolites in Indigofera tirunelvelica Sanjappa. Histochemical screening helps to easily recognize the cell compartment in which the metabolites accumulate. ${ }^{14.15}$ The site of synthesis and accumulation vary for different secondary metabolites. It has been reported that the lipophilic compounds accumulate in membranes, vesicles, extracellular sites or dead cells whereas hydrophilic compounds accumulates in vacuoles. ${ }^{16,17}$ This study reveals the presence of alkaloids in some epidermal, cortical cells and in phloem, xylem regions of the stem and in sclereids, xylem in the root. It has anticholinergic activity and is used to treat smooth muscle spasms, hypersecretion and pain. Other properties of alkaloids are that they inhibit increase in blood glucose level ${ }^{18}$ and act as precursors in the synthesis of corticosteroid drugs which have anti-inflammatory property. ${ }^{19}$ Phenolic compounds have significant medicinal properties including prevention and curing of various skin disorder. ${ }^{20,21}$ Terpenoids and Flavanoids are present in 


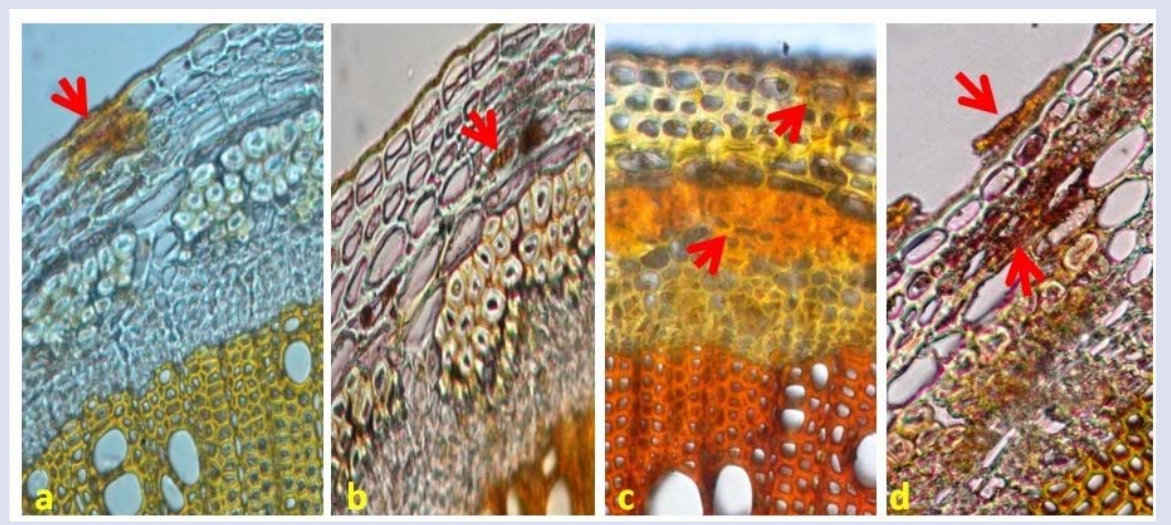

Figure 9: Histochemical localization studies of Indigofera tirunelvelica stem.

a \& b treated with 2-4, dinitrphenylhydrazine suggested the presence of terpenoids in some specialised epidermal cells and cortical cells (a\&b). when treated with dragendroffs reagent. Development of golden yellow colour indicates the presence alkaloids in some epidermal and cortical cells and also in sclereids (c). Sections treated with wagners reagent brown colour formation indicates the presence of alkaloids in epidermal and cortical cells.

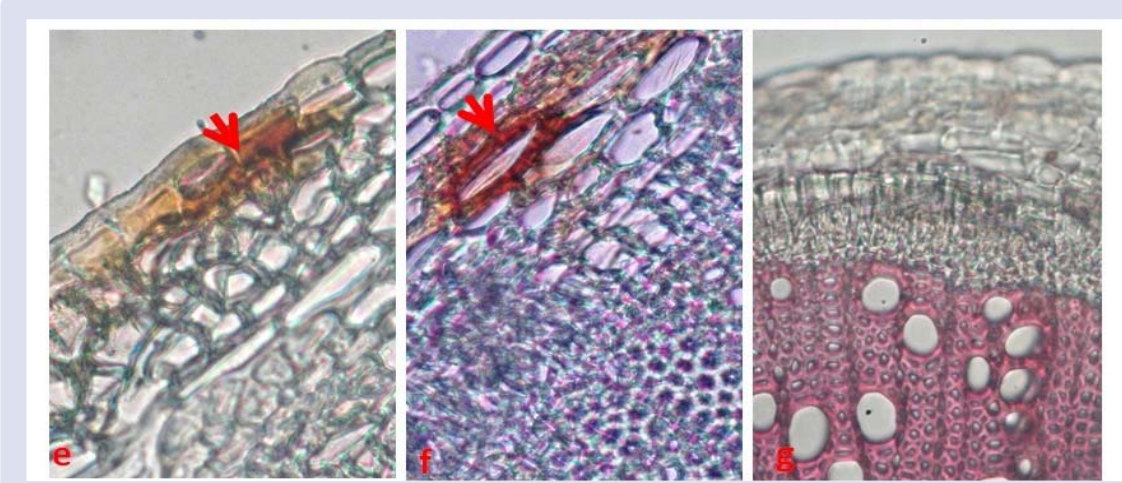

Figure 10: Histochemical localization studies of Indigofera tirunelvelica - stem.

e \& $\mathrm{f}$ treated with $10 \% \mathrm{NaOH}$ (the arrow indicates the presence of flavonoids in some specialised epidermal cells and cortical cells (e \& f). g- sections treated with $10 \%$ phloroglucinol revealed pink colour formation in xylem region indicating the presence of lignin.
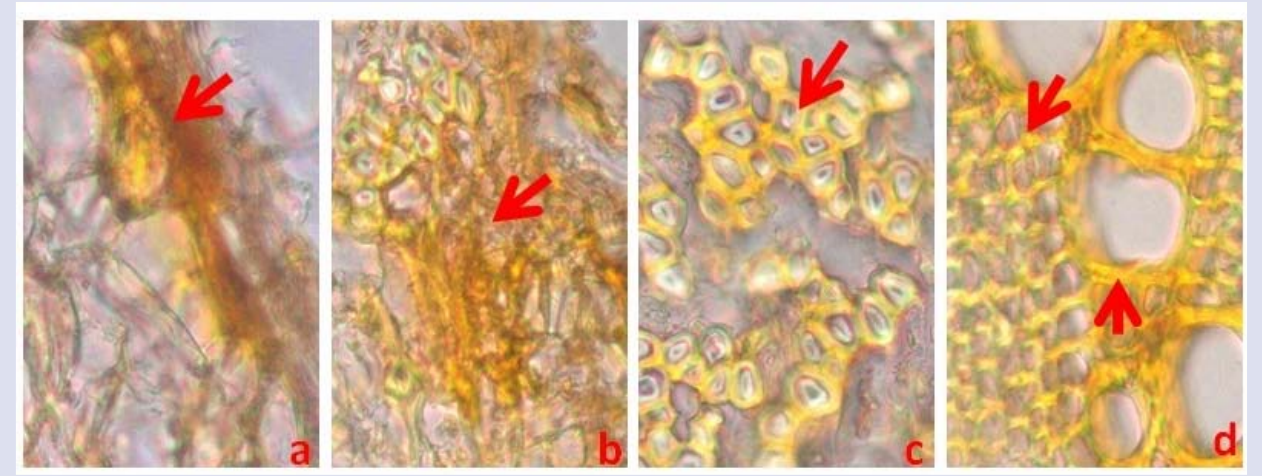

Figure 11: Histochemical localization studies of Indigofera tirunelvelica - root.

a-d treated with 2-4,dinitrphenylhydrazine (arrow indicates the presence of terpenoid in peridermal (a) and cortical cells (b), cell walls of sclereids (c) and in xylem vessels and xylem fibers (d). 


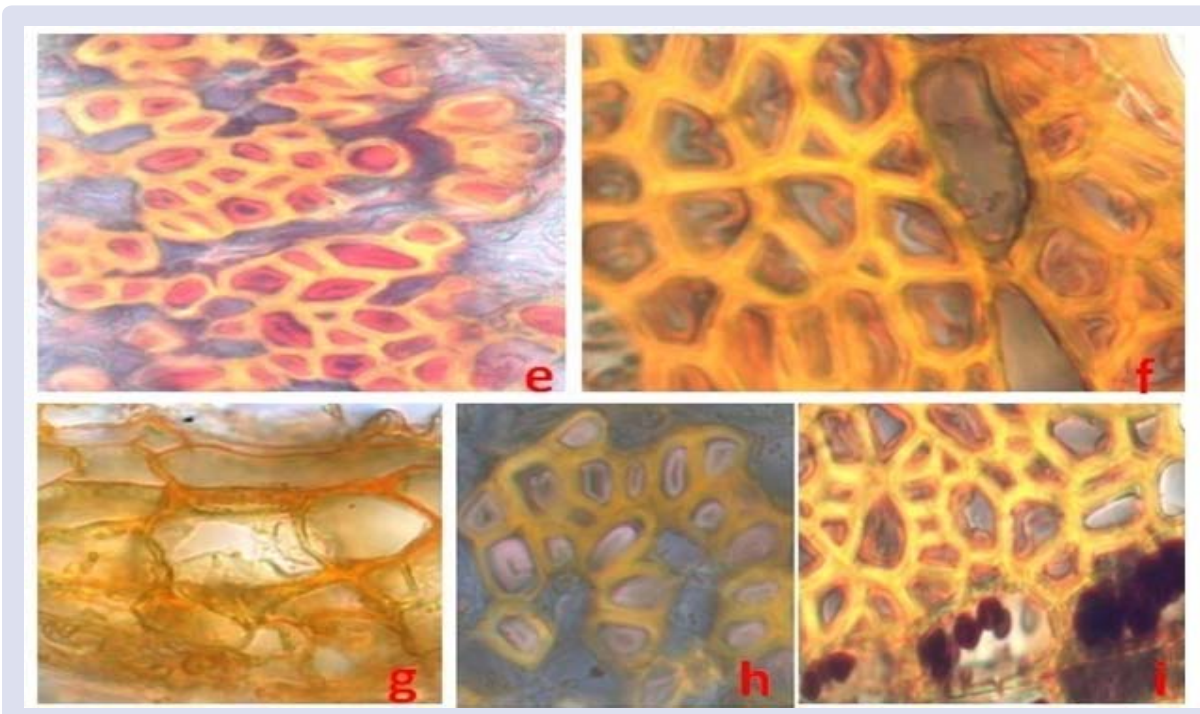

Figure 12: Histochemical localization studies of Indigofera tirunelvelica - root.

e\&f treated with dragendroffs reagent development of golden yellow colour indicates the presence of alkaloids in sclereids and xylem (f); $g$-I treated with wagners reagent, formation of yellowish orange colour indicates the presence alkaloids in peridermal cells (g), sclereids (h) and xylem region (i).

Table 1: Histochemical analysis of stem of Indigofera tirunelvelica.

\begin{tabular}{ccccc}
\hline S.No & Test for & Reagents used & Tissues Localised & Figure \\
\hline 1. & Terpenoids & 2,4-Dinitrophenylhydrazine & $\begin{array}{c}\text { epidermal cells, cortical cells } \\
\text { and xylem region } \\
\text { epidermal, cortical and } \\
\text { phloem cells and xylem } \\
\text { region }\end{array}$ & Fig $9 \mathrm{a}, \mathrm{b}$ \\
2. & Alkaloids & Dragendroff's reagent & $\mathrm{c}, \mathrm{d}$ \\
3. & Flavanoids & $10 \% \mathrm{NaoH}$ & Epidermal,cortical & Fig $10 \mathrm{e}, \mathrm{f}$ \\
4. & Lignin & $10 \%$ Phloroglucinol & xylem region & Fig $10 \mathrm{~g}$ \\
\hline
\end{tabular}

Table 2: Histochemical analysis of root-Indigofera tirunelvelica Sanjappa.

\begin{tabular}{ccccc}
\hline S.No & Test for & Reagents used & Tissues Localised & Figure \\
\hline 1. & Terpenoids & 2,4-Dinitrophenylhydrazine & $\begin{array}{c}\text { periderm, cortical } \\
\text { cells, sclereids and } \\
\text { xylem }\end{array}$ & Fig 11 a-d \\
2. & Alkaloids & Dragendroff's reagent & $\begin{array}{c}\text { scleids and xylem } \\
\text { region } \\
\text { xylem parenchyma, } \\
\text { xylem fibers }\end{array}$ & Fig $12 \mathrm{e}-\mathrm{i}$ \\
3. & Lignin & 10\% Phloroglucinol & only in xylem rays & Fig $13 \mathrm{q}$ \\
\hline
\end{tabular}

epidermal, cortical and xylem of the stem and periderm, sclereids of the root. Tannins are used in the treatment of kidney inflammation, diarrhoea, skin bleeding and transudates. ${ }^{22,23}$

\section{CONCLUSION}

The pharmacognostic evaluation which comprises of macro morphology and microscopic characters, the estimation of physicochemical parameters and the phytochemical and TLC profile are constant features of a plant which are highly essential for raw drugs or plant parts used for preparation of phytomedicine. Therefore, the result generated from this study would be useful in identification and standardization of the plant material Indigofera tirunelveica towards quality assurance and also for preparation of a monograph on the plant. This study is an attempt to establish the botanical identity of the Indigofera tirunelveica as it is a newly discovered plant. The pharmacognostic study will also help to identify the adulterant and authenticate the plant.

\section{ACKNOWLEDGEMENTS}

We would like to thank St. Francis college for women, Begumpet and Srimad Andavan Arts and Science college, Tiruchirappalli for giving the opportunity to do this research work. Our gratitude goes to Dr. Brindha, Associate Dean, Sastra Deemed University, Thanjavur and her team for their technical assistance in performing the anatomical analysis. We owe our thanks to Dr. V. Chelladurai, Professor (Retd.), Department of Botany, Medicinal plant Survey for siddha who helped in the collection and Identification of plant.

\section{CONFLICT OF INTEREST}

The authors have no conflict of interest.

\section{ABBREVIATIONS}

IT: Indigofera tirunelvelica; TS: Transverse section; SC: Sclerenchymata; WHO: World health organization, TLC: Thin layer chromatography. 


\section{REFERENCES}

1. Nostro A, Germanò MP, D'Angelo V, Marino A, Cannatelli MA. Extraction methods and bioautography for evaluation of medicinal plant antimicrobial activity. Letters in Applied Microbiology. 2000;30(5):379-85.

2. Mohammad Saleem TS, Christina AJ, Chidambaranathan N, Ravi V, Gauthaman K. Hepatoprotective activity of Annona squamosal Linn. on experimental animal model. Int J Appl Res Nat Prod. 2008;1:1-7.

3. Ahmad I, Aqil F, Owais M. Modern phytomedicine: turning medicinal plants into drugs. New York: John Wiley \& Sons; 2006.

4. Willow JH. Traditional herbal medicone research methods: identification, analysis, bioassay and pharmaceutical and clinical studies. New York: John Wiley \& Sons; 2011.

5. Benzie IF, Wachtel-Galor S. Herbal medicine: biomolecular and clinical aspects, oxidative stress and disease. 2nd ed. Florida: CRC Press; 2011. Pp: 499.

6. Odugvemi T. A textbook of medicinal plants from Nigeria. Nigeria: ToluOdugbemi; 2008

7. Sanjappa M. A new species of the genus Indigofera (Fabaceae) from India. Journal of Japanese Botany. 1984;59(9): 272-4.

8. Sharma S, Hullatti KK, Prasanna SM, Sharma P. Comparative morphoanatomical and preliminary phytochemical studies of Cuscutareflexa and Cassythafiliformis. Int J Pharma Pharmaceut Sci. 2010;2(1):59-64.

9. Argyropoulou C, Akoumianaki-loannidou A, Christodoulakis NS, Fasseas C. Leaf anatomy and histochemistry of Lippiacitriodora (Verbenaceae). Aust J Bot. 2010;58:398-409.

10. Ferreira PRF, Mendes CSO, Reis SB, Rodrigues CG, Oliveira DA, MercadanteSimões MO. Morphoanatomy, histochemistry and phytochemistry of Psidiumguineense Sw. (Myrtaceae) leaves. J Pharm Res. 2011;4:942-4.

11. Coelho VPM, Leite JPV, Nunes LG, Ventrella MC. Anatomy, histochemistry and phytochemical profile of leaf and stem bark of Bathysa cuspidate (Rubiaceae). Aust J Bot. 2012;60:49-60.

12. Keller U, Tudzynski P. Ergot alkaloids. In: Osiewacz HD, editors. The Mycota. Industrial application. Springer, Berlin, 2002;8:157-181.
13. WHO. Quality control methods for medicinal plant materials. AITBS Publishers \& Distributors, Delhi, 2002.

14. Adams SJ, Kuruvilla GR, Krishnamurthy KV, Nagarajan M, Venkatasubramanian P. Pharmacognostic and phytochemical studies on Ayurvedic drugs Ativisha and Musta. Rev Bras Farmacogn. 2013:23(3):398-409.

15. Bedetti CS, Modolo LV, Isaias RMS. The role of phenolics in the control of auxin in galls of Piptadeniagonoacantha(Mart.) $\mathrm{MacBr}$ (Fabaceae: Mimosoideae) Biochem Syst Ecol. 2014;55:53-9.

16. Matile P. Biochemistry and function of vacuoles in plants, Annu Rev Plant Physiol. 1978;29:193-213.

17. Wink M. Physiology of the accumulation of secondary metabolites with special reference to alkaloids, in Cell Culture and Somatic Cell Genetics of Plants. Constabel F, Vasil I K, editors. Academic Press, San Diego. CA. 1987;4:17-42.

18. Yoshikawa M, Nakamura S, Ozaki K, Kumahara A, Morikawa T, Matsuda $H$. Structures of steroidal alkaloid alisoglycosides, robenesides $A$ and $B$ and antidiabetogenic constituents from the Brazilian medicinal plant Solanumlycocarpum. J Nat Prod. 2007;70:2104.

19. Goswami A, Kotoky R, Rastogi RC, Ghosh AC. A one-pot efficient process for 16 dehydropregnenolone acetate. Org Proc Res Dev. 2003;7:306-8.

20. Santos SC, Mello JCP. Taninos. In: Farmacognosia da planta aomedicamento. Simões CMO, Shenkel EP, Gosmann G, Mello JCP, Mentz LA, Petrovick PR editors. UFSC, Porto Alegre, 2003, pp: 615-656.

21. Dzialo M, Mierziak J, Korzun U, Preisner M, Szopa J, Kulma A. The potentia of plant phenolics in prevention and therapy of skin disorder. Int J Mol Sci. 2016;17(2):160

22. Bernhoft A. A brief review on bioactive compounds in plants. In: Bioactive compounds in plants- benefits and risks for man and animals. The Norwegian Academy of Science and Letters, Oslo, 2010;11-17.

23. Pansera MR, Santos ACA, Paese K, Wasum R, Rossato M, Rota LD et al. Analise de taninostotaisemplanatasaromáticas e medicinaiscultivadas no Nordeste do Rio Grande do Sul. Rev Bras Farmacog. 2003;13:17-22.

\section{GRAPHICAL ABSTRACT}
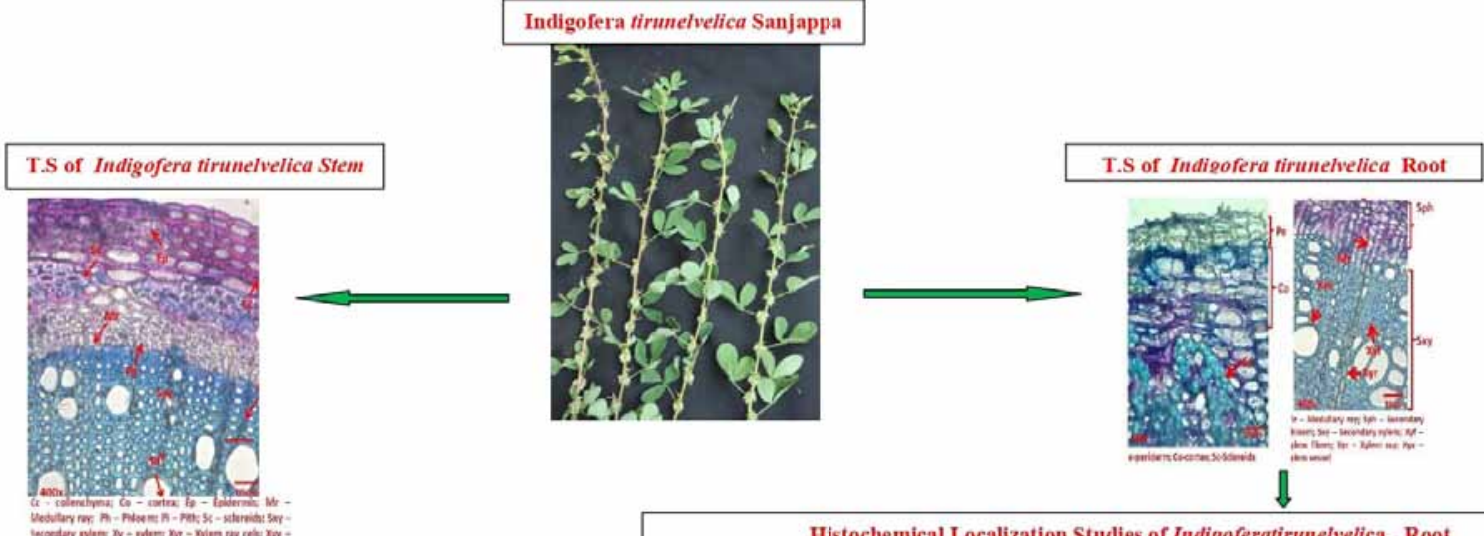

Histochemical Localization Studies of Indigoferatirumelvelica - Root
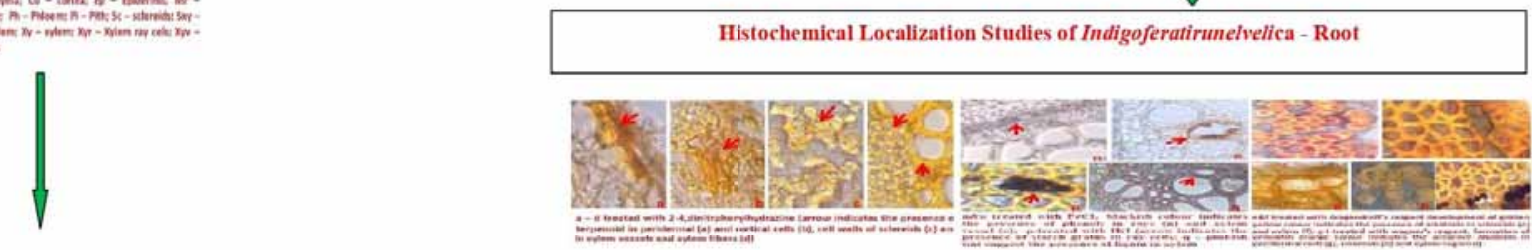

Histochemical Localization Studies of Indigoferatinunelvelica Stem
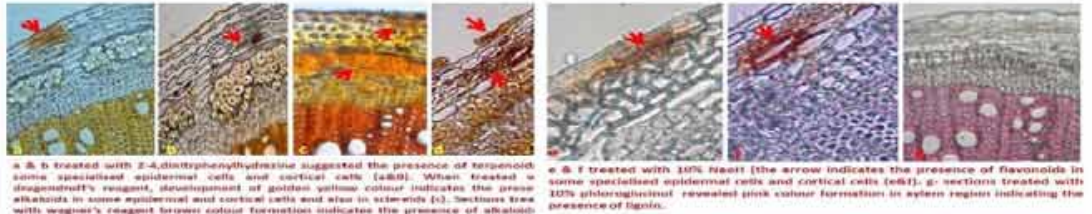


\section{ABOUT AUTHORS}

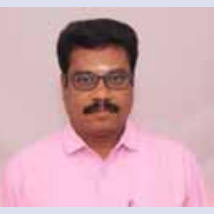

Dr. Agnel Arul John currently works as an Associate Professor and is also the Research Director in Srimad Andavan Arts \& Science college, Trichirappalli. He has 21 years of teaching experience and has won the Best Faculty award by Novel Research Academy in 2019. To his credit he has published 33 research articles with $\mathrm{H}$ index 4 and has 50 citations. He has guided $30 \mathrm{M}$. Phil students and is presently guiding $5 \mathrm{Ph}$.D students.

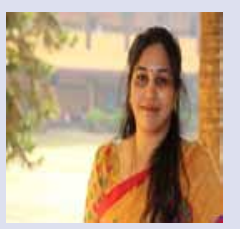

Ms. S. Parijatham Kanchana has Masters in Biochemistry and is pursuing Ph.D on the medicinal plant Indigofera tirunelvelica Sanjappa. She has teaching experience both in India and abroad. Currently she is working as the Asst. Professor in Biochemistry at St. Francis College for Women, Hyderabad.

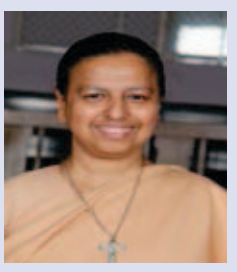

Sr. Sandra Horta has 24 years of teaching experience and is also the founder Head Department of Biochemistry at St. Francis College for Women, Hyderabad. Her specialization in Research is in the field of Enzymology.

Cite this article: Parijatham Kanchana SN, John Nayagam AA, Horta S. Pharmacognostic Profile of Root and Stem of Indigofera Tirunelvelica Sanjappa. Pharmacog J. 2019;11(6)Suppl:1580-6. 